BLACK WIND, WHITE SNOW 

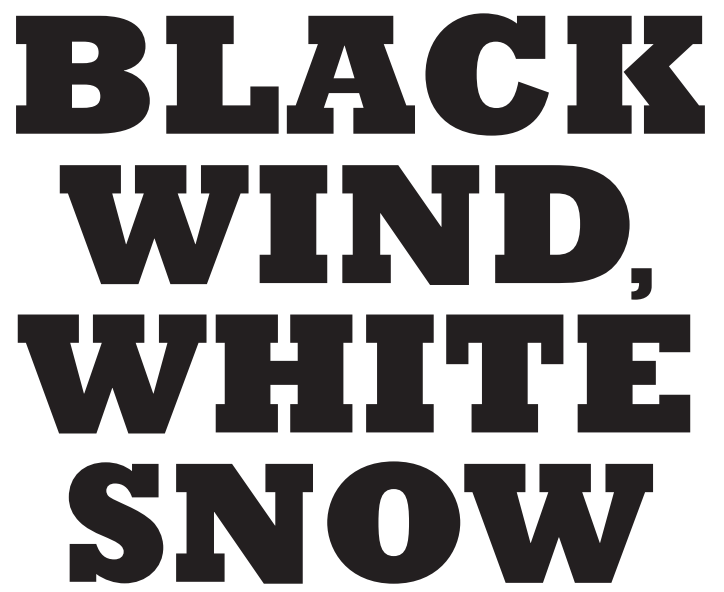

THE RISE OF RUSSIA'S

NEW NATIONALISM

\section{ChaRLES CLOVER}




\section{Copyright (c) 2016 Charles Clover}

All rights reserved. This book may not be reproduced in whole or in part, in any form (beyond that copying permitted by Sections 107 and 108 of the U.S. Copyright Law and except by reviewers for the public press) without written permission from the publishers.

For information about this and other Yale University Press publications, please contact: U.S. Office: sales.press@yale.edu yalebooks.com Europe Office: sales@yaleup.co.uk yalebooks.co.uk

Typeset in Minion Pro by IDSUK (DataConnection) Ltd Printed in Great Britain by Gomer Press, Llandysul, Ceredigion, Wales

Library of Congress Cataloging-in-Publication Data

Clover, Charles, 1968-

Title: Black wind, white snow : the rise of Russia's new nationalism / Charles Clover.

Description: New Haven : Yale University Press, 2016. | Includes bibliographical references and index.

LCCN 2015037501 | ISBN 9780300120707 (hardback)

LCSH: Putin, Vladimir Vladimirovich, 1952-Political and social views. | Putin, Vladimir Vladimirovich, 1952-Friends and associates. | Eurasian school. | Nationalism-Russia (Federation) | Political culture-Russia (Federation) | Russia (Federation)-Politics and government-1991- | Russia (Federation)-Foreign relations-Philosophy. | BISAC: HISTORY / Europe / Russia \& the Former Soviet Union. | HISTORY / Europe / Former Soviet Republics. | HISTORY / Modern / 21st Century. Classification: LCC DK510.766.P87 C56 2016 | DDC 947.086/2092-dc23

LC record available at http://lccn.loc.gov/2015037501

A catalogue record for this book is available from the British Library. 
To Rachel and Jaya 
Now I held in my hands a vast methodical fragment of an unknown planet's entire history, with its architecture and its playing cards, with the dread of its mythologies and the murmur of its languages, with its emperors and its seas, with its minerals and its birds and its fish, with its algebra and its fire ...

Jorge Luis Borges 
